\title{
GAMBARAN TINGKAT PENGETAHUAN IBU MENYUSUI TENTANG MAKANAN PENDAMPING ASI (MP-ASI) DI DESA MRANAK KECAMATAN WONOSALAM KABUPATEN DEMAK TAHUN 2017
}

\section{Overview Knowledge Of Breasting Mothers About Food Coach Mother's Milk In Mranak Village Wonosalam District Demak Regency Year 2017}

\author{
Endang Susilowati \\ Prodi D3 Kebidanan Fakultas Kedokteran \\ Universitas Islam Sultan Agung Semarang \\ (esusilowati27@gmail.com)
}

\begin{abstract}
ABSTRAK
Latar Belakang : Makanan pendamping dibutuhkan untuk memenuhi kebutuhan pangan bayi yang semakin meningkat. Makanan pendamping ASI dapat berupa bubur, tim, sari buah, biskuit. Pemberiannya baik jenis, porsi dan frekuensi tergantung usia dan kemampuan bayi. Dalam hal ini dibutuhkan peran aktif dari sang ibu untuk memberikan MP-ASI sesuai jenis dan usia bayi, karena jika pemberiannya tidak sesuai akan mengakibatkan beberapa dampak diantaranya resiko infeksi saluran pencernaan dan obesitas. Tujuan penelitian ini untuk mengetahui tingkat pengetahuan ibu menyusui tentang makanan pendamping ASI di Desa Mranak Kecamatan Wonosalam Kabupaten Demak.

Metode : Jenis penelitian ini menggunakan jenis penelitian deskriptif dengan pendekatan cross sectional dengan jumlah 55 responden. Instrumen penelitiannya menggunakan kuesioner tertutup.

Hasil : Hasil penelitian menunjukkan bahwa mayoritas responden memiliki tingkat pengetahuan baik sebanyak 49 responden (89\%). Pada kategori pendidikan mayoritas responden memiliki tingkat pendidikan menengah (SMA, SMK, MA, MAK) sebanyak 39 responden $(70,9 \%)$ dengan mayoritas umur $<30$ tahun sebanyak 34 responden $(61,8 \%)$ dan mayoritas sebagai ibu rumah tangga yaitu sebanyak 33 responden $(60 \%)$.

Simpulan : Kesimpulan pada penelitian ini didapatkan tingkat pengetahuan responden baik, mayoritas responden berpendidikan menengah, berumur kurang dari 30 tahun, bekerja sebagai ibu rumah tangga. Ibu menyusui sebaiknya mengikuti penyuluhan yang berkaitan dengan gizi bayi dan balita, konsultasi ke tenaga kesehatan mengenai gizi bayi, memberikan ASI eksklusif sampai bayi berusia 6 bulan, memberikan MP-ASI dimulai saat bayi berusia 6 bulan dengan jenis makanan yang halus dan licin, serta memberikan MP-ASI sesuai jenis dan jadualnya.
\end{abstract}

Kata Kunci : Pengetahuan, Ibu menyusui, Makanan pendamping ASI 


\begin{abstract}
Background:Complementary foods are needed to feed the growing baby. Complementary foods can be pured, teams, fruit juice, biscuits. Both types of administration, and frequency portions dependent baby's age and ability. In this case it takes the active role of the mother to provide appropriate complementary feeding type and age of the baby, as if the gift does not match the impact of which will result in some risk of gastrointestinal infections and obesity. The purpose of this study to determine the level of knowledge about breastfeeding complementary feeding in Mranak Village, Wonosalam District, Demak Regency.

Method:This research uses a descriptive research with cross sectional approach to the number of 55 respondents. Research instrument using enclosed questionnaire.

Result: The results showed that the majority of respondents had a good knowledge level by 49 respondents (89\%). In the education category of the majority of respondents had a secondary education level (high school, vocational school, Madrasah Aliyah, Madrasah Aliyah Vocational) a total of 39 respondents (70.9\%) with the majority aged <30 years as many as 34 respondents (61.8\%) and the majority of the housewives as many as 33 respondents (60\%).

Conclusion: Conclusions in this study, a good level of knowledge, the majority of respondents have secondary education, aged less than 30 years, working as a housewife. Breastfeeding mothers should follow the nutrition counseling relating to babies and toddlers, consulting health professionals about nutrition for infants, exclusive breastfeeding until a baby is 6 months old, giving Complementary feeding begins when the baby is 6 months old with the kind of food that smooth and slippery, and provides Complementary feeding food according to the type and schedule.
\end{abstract}

Keywords : Knowledge, Mother breastfeeding, complementary food

\title{
PENDAHULUAN
}

Makanan Pendamping - Air Susu Ibu (MP-ASI) merupakan makanan atau minuman yang mengandung zat gizi, diberikan kepada bayi atau anak usia 6-24 bulan guna memenuhi kebutuhan gizi selain dari ASI (Depkes RI, 2013, hal. 7). Pemberian MP-ASI mulai dilakukan setelah bayi berusia 6 bulan. MP- ASI dapat berupa bubur, tim, sari buah, biskuit. Pemberian MP-ASI baik jenis, porsi, dan frekuensinya tergantung usia dan kemampuan bayi (Hariyani, 2011; hal. 173).

Cakupan pemberian ASI eksklusif pada bayi 0-6 bulan di Indonesia menunjukkan peningkatan dari 61,3\% tahun 2009 menjadi 61,5\% pada tahun 2010. Namun cakupan pemberian ASI eksklusif pada bayi usia 6 bulan turun dari 34,3\% pada tahun 2009 menjadi 33,6\% pada tahun 2010. Masih rendahnya cakupan pemberian ASI eksklusif dipengaruhi beberapa hal, terutama masih terbatasnya tenaga konselor menyusui di fasilitas pelayanan kesehatan, belum maksimalnya kegiatan edukasi, advokasi dan kampanye terkait pemberian ASI maupun MP-ASI, ketersediaan sarana dan prasarana KIE (Konseling, Informasi dan Edukasi) ASI dan MP-ASI serta belum 
optimalnya pembinaan kelompok pendukung ASI dan MP-ASI (Pedoman Pekan ASI Sedunia, 2012; hal. 10).

Menurut data Profil Kesehatan Jawa Tengah Tahun 2014, jumlah bayi yang mendapatkan ASI eksklusif hanya sekitar 45,18\%, meningkat dibandingkan tahun 2010 (37,18\%). Cakupan tertinggi adalah Kabupaten Klaten 77,55\%, sedangkan yang terendah kedua adalah Kabupaten Demak yaitu sebesar 10,43\%. Berdasarkan data yang diperoleh dari Profil Kesehatan Kabupaten/Kota Demak tahun 2015, cakupan bayi yang diberikan ASI eksklusif dari 27 puskesmas, puskesmas Wonosalam I menduduki peringkat kedua status gizi baik pada balita yaitu sebesar $88,09 \%$.

Pemberian MP-ASI sebelum waktunya di wilayah kerja Puskesmas Wonosalam I masih cukup banyak yaitu tercatat pada bulan Desember 2016 terdapat bayi dengan umur 0-6 bulan sebanyak 361 bayi, yang diberikan ASI eksklusif hanya 218 bayi $(60,38 \%)$ dan yang mendapatkan MP-ASI sebanyak 143 bayi $(39,62 \%)$, dan yang paling tinggi pemberian MP-ASI sebelum waktunya terdapat di desa Mranak yaitu sebanyak 21 bayi dari 41 bayi usia 0-6 bulan.

Permasalahan pemberian MP-ASI yang tidak sesuai disebabkan oleh beberapa faktor, diantaranya faktor pendidikan, faktor sosial budaya, faktor lingkungan dan faktor ekonomi. Faktor pendidikan biasanya dikaitkan dengan pengetahuan, yang selanjutnya dapat berpengaruh terhadap pemilihan bahan makanan dan kebutuhan gizi. Faktor sosial budaya cenderung pada kepercayaan yang mempengaruhi konsumsi jenis makanan tertentu karena dianggap sebagai pantangan. Faktor lingkungan yang dimaksudkan seperti lingkungan keluarga, sekolah, dan sebagainya, misalkan lingkungan keluarga, kebiasaan makan dalam keluarga akan memberikan pengaruh terhadap pemberian MP-ASI. Faktor ekonomi erat hubungannya dengan pendapatan keluarga dan harga pangan di pasaran. Rendahnya pendapatan keluarga jelas terlihat kurang dalam pemenuhan gizi keluarga, begitupun dengan tingginya pendapatan yang tidak diimbangi pengetahuan gizi yang cukup, akan menyebabkan seseorang menjadi sangat konsumtif dan tidak terkontrol dalam pemberian MP-ASI sehingga bayi dapat menjadi obesitas (Hariyani, 2011; hal. 52-55).

Dampak apabila memberi MP-ASI yang jenisnya tidak sesuai umur bayi, maka akan lebih sulit untuk memenuhi kebutuhan nutrisi bayi. Disamping itu resiko infeksi saluran pencernaan kemungkinan bisa terjadi (Ria, 2012; hal. 5-6). Berdasarkan studi pendahuluan yang dilakukan dengan wawancara terhadap 20 responden, di Posyandu Desa Mranak Kecamatan Wonosalam Kabupaten Demak, didapatkan bahwa $80 \%$ ibu menyusui rata-rata mengatakan bahwa memberikan makanan pendamping kepada bayinya sejak usia 4-5 bulan, bahkan terdapat 1 ibu yang memberikan makanan pendamping mulai dari usia anak masih 1 bulan. Sedangkan untuk jenis makanan yang pertama kali diberikan adalah bubur, mulai memberikan nasi tim pertama kali rata-rata saat bayi usia 8 bulan. 
Berdasarkan uraian di atas, maka penulis tertarik untuk melakukan penelitian tentang "Gambaran Tingkat Pengetahuan Ibu Menyusui Tentang MP-ASI".

\section{METODE PENELITIAN}

Penelitian ini menggunakan jenis penelitian deskriptif dengan pendekatan cross sectional. Populasi dalam penelitian ini adalah ibu menyusui yang mempunyai bayi usia 0-24 bulan yang memberikan MP-ASI di Desa Mranak Kecamatan Wonosalam Kabupaten Demak, sebanyak 55 responden. Sampel yang digunakan adalah semua ibu menyusui yang mempunyai bayi usia 0-24 bulan yang memberikan MP-ASI di Desa Mranak Kecamatan Wonosalam Kabupaten Demak sebanyak 55 responden.

Pengumpulan data dalam penelitian ini adalah dengan menggunakan kuesioner dengan pertanyaan tertutup tentang pengetahuan ibu menyusui yang memberikan makanan pendamping ASI pada bayi usia 0-24 bulan. Data primer yaitu diambil dari pengumpulan data kuesioner yang diisi langsung oleh responden sedangkan pengumpulan data sekunder dilakukan dengan cara melihat dokumen-dokumen atau catatan-catatan yang mendukung data penelitian diantaranya Pedoman Pekan ASI Sedunia, Dinas Kesehatan Provinsi Jawa Tengah tahun 2015, Dinas Kesehatan Kabupaten Demak dan data rekapitulasi pencatatan ASI eksklusif di Puskesmas Wonosalam I tahun 2016.

\section{HASIL DAN PEMBAHASAN}

1. Karakteristik Responden

a. Tingkat Pendidikan

Diagram 1 Distribusi Frekuensi Tingkat Pendidikan Ibu Menyusui yang Memberikan Makanan Pendamping ASI

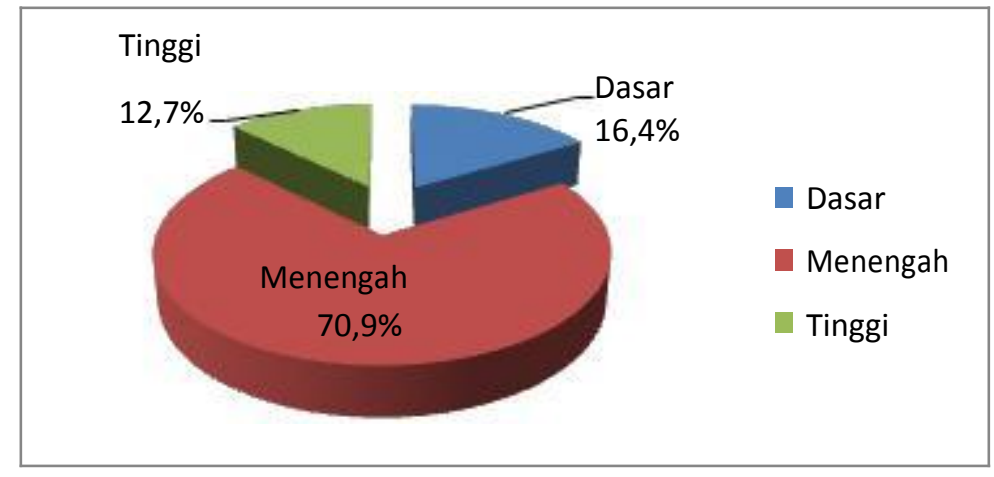

Berdasarkan Diagram 1 menunjukkan bahwa mayoritas responden dengan tingkat pendidikan menengah yaitu sebanyak 39 
orang $(70,9 \%)$, dan responden dengan tingkat pendidikan tinggi hanya sebanyak 7 orang $(12,7 \%)$.

b. Umur

Diagram 2 Distribusi Frekuensi Umur Ibu Menyusui yang Memberikan Makanan Pendamping ASI

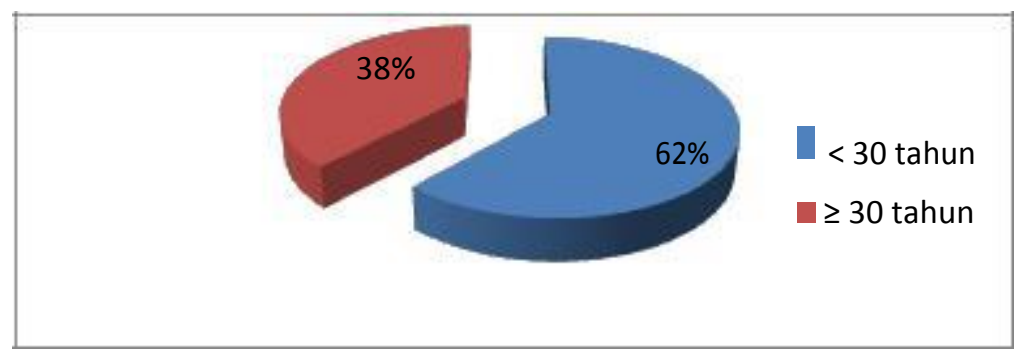

Berdasarkan Diagram 2 menunjukkan bahwa mayoritas responden dengan umur kurang dari 30 tahun, yaitu sebanyak 34 orang $(61,8 \%)$, dan selebihnya 21 orang $(38,1 \%)$ berumur lebih dari sama dengan 30 tahun.

c. Pekerjaan

Diagram 3 Distribusi Frekuensi Pekerjaan Ibu Menyusui yang Memberikan Makanan Pendamping ASI

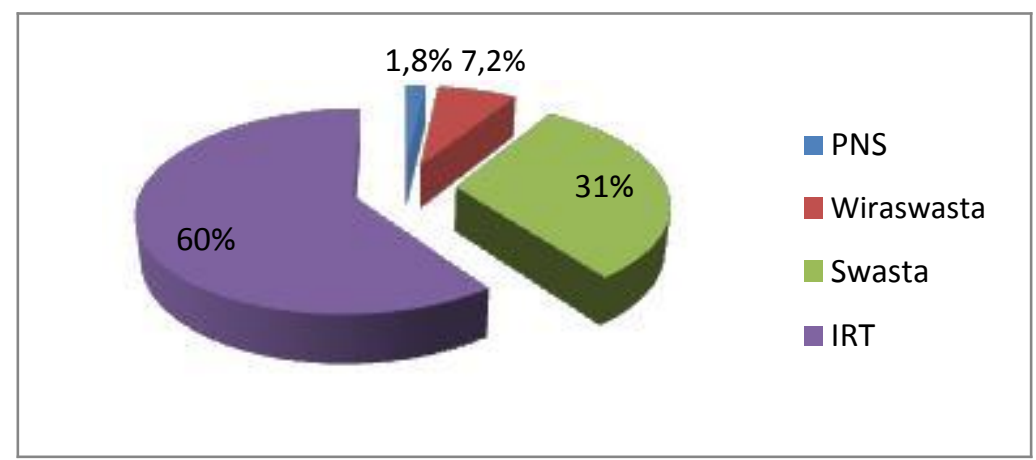

Berdasarkan Diagram 3 menunjukkan bahwa mayoritas responden kegiatan sehari-harinya sebagai ibu rumah tangga, yaitu sebanyak 33 orang (60\%), sedangkan pekerjaan paling sedikit yaitu ibu yang bekerja sebagai Pegawai Negeri Sipil sebanyak 1 orang $(1,8 \%)$. 
2. Tingkat Pengetahuan

Diagram 4 Distribusi Frekuensi Tingkat Pengetahuan Ibu Menyusui tentang Makanan Pendamping ASI

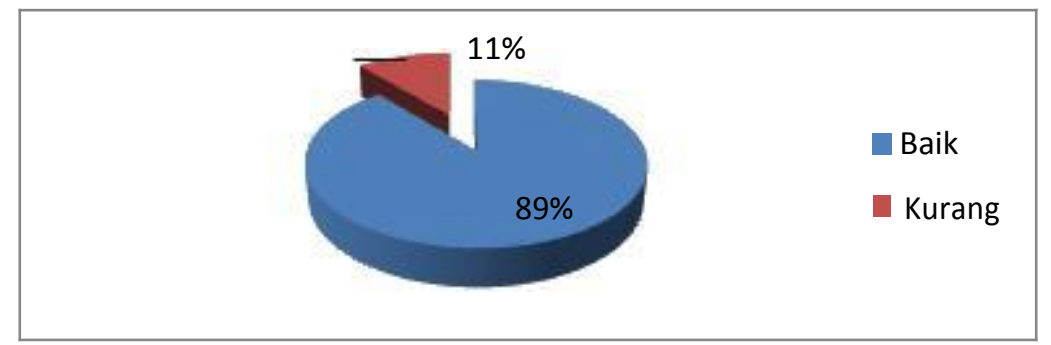

Berdasarkan Diagram 4 pengetahuan responden tentang MP-ASI, responden dengan pengetahuan baik sebanyak 49 responden (89\%), sedangkan responden yang memiliki pengetahuan kurang sebanyak 6 responden (11\%).

Berdasarkan hasil penelitian, menunjukkan bahwa mayoritas responden berpendidikan menengah (SMA/SMK/MA) yaitu sebanyak 39 responden (70,9\%). Hal ini menunjukkan bahwa sebagian besar responden memiliki tingkat pendidikan menengah.

Berdasarkan teori Nursalam (2013), pendidikanmenengah merupakan lanjutan pendidikan dasar, terdiri atas pendidikan menengah umum dan pendidikan menengah kejuruan. Pendidikan menengah berbentuk Sekolah Menengah Atas (SMA), Madrasah Aliyah (MA), Sekolah Menengah Kejuruan (SMK), dan Madrasah Aliyah Kejuruan (MAK), atau bentuk lain yang sederajat.

Pendidikan merupakan salah satu wadah bagi seseorang dalam memperoleh pengetahuan, sedangkan pengetahuan itu hal utama pembentuk tindakan seseorang. Pendidikan tersebut merupakan dasar dalam menentukan respon terhadap rangsangan yang datang dalam kehidupan baik itu rangsangan yang bersifat positif maupun negatif, sehingga akan mengarah ke perilaku, termasuk perilaku kesehatan. Pendidikan itu sendiri terbagi dalam pendidikan formal dan informal. Pendidikan formal merupakan pendidikan yang diselenggarakan di sekolah-sekolah umumnya, sedangkan pendidikan informal didapat dari lingkungan keluarga yang berupa ajaran tata krama, sikap dan tingkah laku yang diajarkan oleh anggota keluarga (seperti orang tua) sejak lahir. Pendidikan informal dapat juga disebut pendidikan yang ada di masyarakat, atau pendidikan yang dialami oleh seseorang di lingkungannya.

Sesuai keadaan di lapangan, mayoritas responden mengikuti berbagai macam kegiatan yang termasuk dalam pendidikan informal, seperti kegiatan posyandu, kegiatan Pemberdayaan Kesejahteraan Keluarga (PKK), dan kegiatan keagamaan. Hal tersebut menunjukkan bahwa pengetahuan responden tidak hanya didapat dari pendidikan formal saja melainkan juga informal, sehingga walaupun mayoritas ibu- 
ibu dengan tingkat pendidikan menengah, tetapi ibu-ibu masih banyak peluang untuk mendapatkan pengetahuan, yaitu dari pendidikan informal, maka dari itu berdasarkan hasil penelitian ibu-ibu memiliki tingkat pengetahuan baik.

Hasil penelitian yang dilakukan oleh Pertiwi (2011), dengan judul Hubungan Tingkat Pengetahuan Ibu tentang Makanan Pendamping ASI (MP-ASI) terhadap Berat Badan Bayi usia 6-24 bulan di Kelurahan Barusari Kecamatan Semarang Selatan Kota Semarang, menunjukkan bahwa mayoritas pendidikan ibu yang menjadi responden penelitian adalah tamat SMA yaitu sebanyak 37 ibu (45\%), dan terendah dengan pendidikan tamat SD yaitu sebanyak 3 ibu $(3,7 \%)$. Pendidikan ibu yang rendah memungkinkan seorang ibu kurang dalam mengadopsi pengetahuan yang baru dan akan menghambat sikap seorang ibu terhadap informasi khususnya tentang hal-hal yang berhubungan dengan makanan pendamping ASI.

Berdasarkan hasil penelitian, menunjukkan bahwa mayoritas responden berumur kurang dari 30 tahun $(61,8 \%)$. Hal ini menunjukkan bahwa tingkat kedewasaan responden dalam batas dewasa awal.

Menurut teori Santrock (2009), yang menyatakan bahwa masa awal dewasa (early adulthood) ialah periode perkembangan yang bermula pada akhir usia belasan tahun atau awal usia duapuluhan tahun dan yang berakhir pada usia tigapuluhan tahun. Ini adalah masa pembentukan kemandirian pribadi dan ekonomi, masa perkembangan karir, dan bagi banyak orang, masa pemilihan pasangan, belajar hidup dengan seseorang secara akrab, memulai keluarga dan mengasuh anak-anak.

Dewasa awal merupakan dimana proses perkembangan mental, psikologis dan sosiologis sedang berlangsung. Pada umur ini seorang wanita sudah mempunyai kepribadian yang matang dan berfikir untuk masa depan. Semakin matangnya cara berfikir seseorang, maka semakin memperoleh banyak pengetahuan. Dalam hal ini adalah kematangan berfikir menentukan perilaku kesehatan, bukan hanya bagi dirinya saja tetapi juga bagi keluarganya, termasuk berfikir kapan memberikan MPASI dan apa saja jenis yang diberikan kepada buah hatinya disesuaikan dengan pengetahuan yang telah didapatkannya. Hal ini sejalan dengan penelitian Pertiwi (2011) yang berjudul Hubungan Tingkat Pengetahuan Ibu tentang Makanan Pendamping ASI (MP-ASI) terhadap Berat Badan Bayi usia 6-24 bulan di Kelurahan Barusari Kecamatan Semarang Selatan Kota Semarang, menunjukkan bahwa mayoritas usia responden terbanyak adalah pada usia 21-30 tahun, sebanyak 53 ibu $(65,4 \%)$. Berdasarkan hasil tersebut dapat diketahui bahwa rata-rata umur responden telah mencapai umur dewasa aktif, sehingga mempunyai tingkat kematangan emosional yang telah matang.

Akan tetapi hasil penelitian di lapangan, tidak semua ibu-ibu menyusui yang berusia dewasa awal mempunyai tingkat kematangan berfikir yang baik. Ditemukan beberapa ibu terutama ibu muda masih 
belum yakin bahkan bingung dengan informasi yang diterimanya, terkait dengan usianya yang masih muda dan belum mempunyai pengalaman dalam mengasuh anak. Terlihat dari cara ibu mencerna pernyataan masih kurang paham dan masih sering bertanya kepada peneliti maksud dari pernyataan dan jawaban yang benarnya seperti apa. Hal ini menunjukkan bahwa umur tidaklah selalu menjadi patokan untuk menentukan tingkat pengetahuan seseorang.

Berdasarkan hasil penelitian, menunjukkan bahwa mayoritas responden bekerja sebagai ibu rumah tangga yaitu sebanyak 33 responden (60\%). Hal ini menunjukkan bahwa mayoritas ibu hanya melakukan pekerjaan rumah sehingga ibu akan lebih bisa memantau perkembangan anaknya dengan baik.

Akses dalam memperoleh pengetahuanpun antara ibu rumah tangga dan ibu yang bekerja di luar rumah akan jauh berbeda, dimana ibu rumah tangga memiliki banyak waktu di rumah sehingga waktu yang digunakan untuk mengurus keluarga lebih banyak serta ada waktu pula untuk mengikuti kegiatan bermasyarakat yang kaitannya dengan kesehatan, seperti membawa anaknya ke posyandu setiap bulan sehingga mendapatkan informasi melalui penyuluhan dari kader ataupun tenaga kesehatan setempat, misalnya kegiatan lain seperti PKK, dan sebagainya.

Lain halnya dengan ibu yang bekerja akan memiliki sedikit waktu dalam keluarga dan di lingkungan masyarakat sehingga jarang mengikuti kegiatan -kegiatan kemasyarakatan, bahkan karena hal tersebut ada pula ibu yang menitipkan anaknya kepada pengasuh atau baby sister sehingga ibu kurang memantau dan mengetahui perkembangan anak secara langsung. Walaupun menurut Mubarak (2011; 83), lingkungan pekerjaan dapat membuat seseorang memperoleh pengalaman dan pengetahuan, baik secara langsung maupun tidak langsung. Namun yang terjadi di lapangan, justru ibu yang bekerja di luar rumah akan menjadi sangat sibuk terutama yang pekerjaannya swasta (sebanyak 17 responden atau $31 \%$ ) sering lembur sehingga pada saat di lingkungan pekerjaan hanya fokus pada pekerjaannya saja, bahkan kurang memperhatikan informasiinformasi yang didapatnya dari luar.

Dalam penelitian ini sejalan dengan penelitian Septiana (2009) yang berjudul Hubungan Pola Pemberian Makanan Pendamping ASI (MPASI) dan Status Gizi Balita Usia 6-24 bulan di wilayah kerja Puskesmas Godongtengen Yogyakarta, dengan 74 responden dimana mayoritas responden adalah ibu rumah tangga (64,87\%), meskipun demikian ibu yang hanya bekerja sebagai ibu rumah tangga biasanya memiliki pola asuh yang lebih baik terhadap tumbuh kembang balita daripada ibu dengan pekerjaan diluar rumah atau pekerjaan lain, dengan pola asuh yang baik maka ibu dapat melihat tumbuh kembang anak lebih baik atau lebih fokus dalam merawat dan mengasuh anak. 
Berdasarkan hasil penelitian, menunjukkan bahwa mayoritas responden memiliki pengetahuan yang baik tentang makanan pendamping ASI, yaitu sebanyak 49 responden (89\%). Menurut Nursalam (2012),pengetahuan merupakan hasil tahu dan ini terjadi setelah orang melakukan pengindraan terhadap suatu objek tertentu. Faktor yang mempengaruhi pengetahuan diantaranya adalah pendidikan, umur, pekerjaan, pengalaman, faktor eksternal (lingkungan dan sosial budaya).

Dari tingkat pendidikan, mayoritas responden memiliki tingkat pendidikan menengah, tetapi pengetahuan responden baik. Hal ini berhubungan dengan faktor yang mempengaruhi tingkat pengetahuan menurut Nursalam (2012) yang tersebut di atas. Faktor yang paling menonjol di lapangan yaitu faktor eksternal. Diantaranya faktor lingkungan dan faktor sosial budaya (turun temurun).

Faktor lingkungan misalnya pada saat ibu-ibu berkumpul dan membicarakan tentang gizi sang buah hati, kemudian ada ibu yang menyampaikan bahwa ibu tersebut memberikan MP-ASI dimulai usia anak 4 bulan dengan bubur halus, dan terlihat anaknya tumbuh gemuk dan sehat, sehingga ibu-ibu yang lain akan meniru walaupun sudah tahu sebenarnya pemberian MP-ASI mulai usia bayi 6 bulan.

Faktor turun temurun disini pihak keluarga ikut andil dalam menentukan jenis dan waktu pemberian MP-ASI, misalnya nenek dari sang bayi menganjurkan kepada ibu untuk memberikan MP-ASI pada anak mulai usia 4 bulan, karena pengalaman sebelumnya nenek memberikan MP-ASI kepada anak-anaknya mulai dari usia 4 bulan, dan anak-anaknyapun bisa tumbuh sehat.

Hal ini sejalan dengan penelitian Rohmatika (2011) dengan judul Hubungan Tingkat Pengetahuan Ibu dengan Pemberian Makanan Pendamping ASI Bayi Umur 6- 24 bulan di Posyandu Karyamulya Jetis Jaten, menunjukkan bahwa ada hubungan yang sangat bermakna antara variabel tingkat pengetahuan ibu dengan pemberian makanan pendamping ASI. Dari 30 responden yang diteliti, untuk kategori baik pada pemberian makanan pendamping ASI sebanyak $26(86,7 \%)$ responden, yang sebagian besar adalah responden dengan tingkat pengetahuan baik yaitu sebanyak $21(70,0 \%)$ responden. Hal ini dapat terjadi karena walaupun tingkat pengetahuan ibu baik tetapi dipengaruhi oleh budaya setempat, tradisi keluarga serta anggapan bahwa ASI saja tidak cukup untuk memenuhi kebutuhan bayi.

Selain faktor-faktor yang mempengaruhi pengetahuan, Notoatmodjo (2010) menyebutkan ada 6 tahapan dalam pengetahuan yaitu tahu, memahami, aplikasi, analisis, sintesis, dan evaluasi. Dalam teori ini dijelaskan bahwa seseorang yang telah mengetahui suatu materi (tahu), kemudian dapat menjelaskan secara benar materi yang diketahuinya itu (memahami), lalu menggunakan materi yang telah dipelajari tersebut dalam kehidupan sehari-hari (aplikasi). 
Namun faktanya di lapangan, seseorang yang sudah mengetahui suatu hal atau materi, justru tidak mengaplikasikannya sesuai dengan apa yang telah diketahuinya itu. Dilihat dari hasil penelitian, responden yang memiliki tingkat pengetahuan baik, justru malah memberikan MPASI pada bayi usia kurang dari 6 bulan. Jika dilihat dari distribusi jawaban, pengetahuan responden tentang MP-ASI hanya sebatas tahu tujuan pemberian MP-ASI dan pengertian dari MP-ASI itu sendiri. Banyak yang belum mengetahui tentang waktu pemberian, jenis dan jadual pemberian MP-ASI, padahal itu adalah hal yang paling penting untuk diketahui oleh responden terkait dengan pemberian MP-ASI kepada bayinya, sehingga tidak heran jika masih banyak masyarakat yang memberikan MP-ASI sejak usia bayinya kurang dari 6 bulan dan pemberian jenisnya kurang tepat.

Kurangnya pengetahuan responden tentang waktu pemberian, jenis dan jadual pemberian MP-ASI menjadikan kontras antara hasil penelitian tingkat pengetahuan dengan perilaku ibu menyusui, karena pada kenyataan hampir seluruh ibu menyusui memberikan MP-ASI dengan jenis dan waktu yang tidak sesuai usia bayi, pada hasil studi pendahuluan dengan cara wawancara langsung terhadap 40\% dari responden, didapatkan hasil bahwa bayi usia 4 bulan sudah diberikan bubur halus, dan ketika usia 6 bulan sudah diberikan nasi uleg.

Berdasarkan hasil penelitian, tingkat pengetahuan ibu baik, sedangkan perilaku ibu kurang, maka akan menimbulkan berbagai dampak. Dampak yang akan timbul diantaranya akan menyebabkan terjadinya gangguan pencernaan, mempengaruhi pertumbuhan dan perkembangan sang bayi, misalnya bayi yang diberikan MP-ASI sejak usia kurang dari 6 bulan dan porsi yang berlebih, maka dapat menyebabkan bayi mengalami obesitas. Bayi yang mengalami obesitas, maka akan mengalami keterlambatan dalam pertumbuhannya, karena dengan berat badan yang berlebih bayi akan lebih malas beraktifitas terutama yang berhubungan dengan motorik kasarnya.

Seyogyanya jika tingkat pengetahuan seseorang baik, maka akan berperilaku baik pula. Hal ini sesuai dengan teori Notoatmodjo (2010; hal. 140-142), pengetahuan merupakan domain yang sangat penting untuk terbentuknya tindakan seseorang.

\section{SIMPULAN DAN SARAN}

\section{Simpulan}

Berdasarkan hasil penelitian didapatkan bahwa tingkat pengetahuan responden mayoritas baik. Berdasarkan hasil penelitian didapatkan bahwa mayoritas tingkat pendidikan responden adalah tingkat menengah, umur kurang dari 30 tahun dan pekerjaannya ibu rumah tangga. 


\section{Saran}

Bagi Responden diharapkan mengikuti penyuluhan gizi oleh tenaga kesehatan setempat, konsultasi ke tenaga kesehatan tentang gizi bayi, memberikan ASI secara eksklusif sampai bayi usia 6 bulan, memberikan MPASI dimulai saat bayi berusia 6 bulan dangan jenis makanan halus dan licin, memberikan MP-ASI sesuai jenis dan jadual. Bagi Tenaga Kesehatan diharapkan memberikan leaflet tentang MP-ASI kepada ibu menyusui, memberikan dukungan penuh kepada masyarakat khususnya ibu-ibu yang mempunyai bayi untuk memberikan ASI eksklusif sampai bayi berusia 6 bulan dilanjutkan pemberian MP-ASI sesuai dengan waktu dan jenisnya, melakukan kunjungan rumah untuk memantau perilaku ibu menyusui agar dapat memberikan MP-ASI secara benar dan tepat, Bidan mengajarkan cara pembuatan MP-ASI yang tepat sesuai usia bayi. Bagi Peneliti Selanjutnya diharapkan penelitian ini dapat dikembangkan untuk penelitian selanjutnya yang lebih variatif, terkait dengan hubungan tingkat pengetahuan ibu menyusui tentang ASI eksklusif dengan perilaku ibu memberikan MP-ASI berdasarkan waktu dan jenis pemberiannya, ditambah dengan karakteristik ibu.

\section{DAFTAR PUSTAKA}

Departeman Kesehatan Republik Indonesia. 2015 "Pofil Kesehatan Indonesia"

Departeman Kesehatan Republik Indonesia. 2012 "Pedoman Pekan ASI Sedunia".

Dinas Kesehatan Jawa Tengah. 2014 "Profil Kesehatan Jawa Tengah". Dinas

Kesehatan Kota Demak. 2015 "Profil Kesehatan Kabupaten Demak”. Mubarak, Wahit Iqbal. 2011. Promosi Kesehatan untuk Kebidanan. Jakarta :

Salemba Medika.

Notoatmodjo, S. 2010. Ilmu Kesehatan Masyarakat. Jakarta: Rineka Cipta. . 2010. Metodologi Penelitian Kesehatan. Jakarta: Rineka Cipta.

Nursalam. 2012. Konsep dan Penerapan Metodologi Penelitian Ilmu Kesehatan. Jakarta: Salemba Medika. . 2013. Metodologi Penelitian: Pendekatan Praktik (Edisi 3). Jakarta: Salemba Medika.

Pertiwi, Ika S. 2011. Hubungan Pengetahuan Ibu Tentang Makanan Pendamping Asi (MP-ASI) Terhadap Berat Badan Bayi Usia 6-24 Bulan di Kelurahan Barusari Kecamatan Semarang Selatan Kota Semarang.

[diunduh 22 Mei 2013]. Tersedia dari: http://ejournal.stikestelogorejo.ac.id/.

Riksani, Ria. 2012. Variasi Olahan Makanan Pendamping ASI. Jakarta: Dunia Kreasi.

Rohmatika, Dheny. 2011. Hubungan Tingkat Pengetahuan Ibu dengan Pemberian Makanan Pendamping ASI Bayi Umur 6-24 Bulan Di 
Avicenna Journal of Health Research. Vol 1 No 1. Maret 2018 (1 - 12)

Posyandu KaryaMulya Jetis Jaten. [diunduh 22 Mei 2015]. Tersedia dari: http:// jurnal.stikeskusumahusada.ac.id/.

Santrock, John W, 2009. Perkembangan Anak. Edisi 11. Jakarta. Erlangga

Septiana, Rika. 2011. Hubungan antara Pola Pemberian Makanan Pendamping

ASI (MP-ASI) dan Satus Gizi Balita Usia 6-24 bulan di Wilayah Kerja Puskesmas Gedongtengen Yogyakarta . [diunduh 22 Mei 2015].

Tersedia dari: http://journal.uad.ac.id/.

Sulistyoningsih, Hariyani. 2011. Gizi untuk Kesehatan Ibu dan Anak.

Yogyakarta: Graha Ilmu. 
